\title{
高温超伝導体薄膜の作製·評価技術の現状 $(4)$
}

\section{Bi 系高温超伝導体の薄膜化}

\author{
広 地 久美子・和 佐 清 孝 \\ 松下電器中央研究所 $\overline{\mathbf{T}} 570$ 守口市八雲中町 3-15
}

(1989 年. 3 月 27 日 受理)

\section{Thin Film Processing for High- $T_{c}$ Superconductors of Bi-System}

\author{
Kumiko HIROCHI and Kiyotaka WASA \\ Central Research Laboratories, Matsushita Electric Co. Ltd. \\ 3-15 Yagumonakamachi, Moriguchi-shi 570
}

(Received March 27, 1989)

Basic thin film deposition processes for the high- $T_{\mathrm{c}}$ superconductors of Bi-systems are described in relation to their structure and superconducting properties.

For the rare-earth high- $T_{\mathrm{c}}$ superconductors $\mathrm{YBC}$ the thin film deposition processes are clasified into three processes:

(i) deposition below crystallizing temperature followed by annealing [process (1)],

(ii) deposition above crystallizing temperatme followed by annealing [process (2)],

(iii) deposition above crystallizing temperature without postannealing [process ( 3 )].

For the $\mathrm{Bi}$-system there appear several superconducting phases including the low- $T_{\mathrm{c}}$ phase $\mathrm{Bi}_{2} \mathrm{Sr}_{2} \mathrm{Ca}_{2} \mathrm{Cu}_{2} \mathrm{O}_{x}$ and the high- $T_{c}$ phase $\mathrm{Bi}_{2} \mathrm{Sr}_{2} \mathrm{Ca}_{2} \mathrm{Cu}_{3} \mathrm{O}_{x}$. Thin films with these superconducting phases are synthesized by a selection of the substrate temperature $T_{s}$ during the deposition in the process (1) and/or (2): The high- $T_{\mathrm{c}}$ phase with $T_{\mathrm{c}} \simeq 110 \mathrm{~K}$ is synthesized at $T_{\mathrm{s}}>800^{\circ} \mathrm{C}$; the low$T_{\mathrm{c}}$ phase with $T_{\mathrm{c}}=80 \mathrm{~K}$, at $T_{\mathrm{s}}<600^{\circ} \mathrm{C}$. However, these films often comprise intergrowth structure between the different superconducting phases.

The close control of the supercondurting phase has been achieved by the layer-by-layer deposition in the atomic layer epitaxy process.

\section{1.はじめに}

Müller と Bednorz が LBC 系の高温超伝導体を発見 して以来, はや 2 年余が経過した。この間, YBC 系を はじめとする希土類系材料, $\mathrm{Bi}, \mathrm{Tl}$ 系の非希土類系材 料が発見された。これらは，いずれも $\mathrm{Cu}-\mathrm{O}$ 層を含ん でいるが， $\mathrm{Cu}-\mathrm{O}$ 層を含まない超伝導材料む発見され， 高温超伝導体の種類も急速に増加しつつある。Table 1 にこれらの種類と基本特性を示す 1 19)。

このような高温超伝導体は, 一般にはセラミックス状 態である。基礎的な物性を調べたり，あるいはエレクト ロニクスへの応用を考える時, 一般には薄膜化が必要で ある。一方, この種の材料は, ペロブスカイト構造をも つため, 薄膜化の手法は, 従来から研究されているぺロ ブスカイト構造強誘電体の薄膜化の方法に従うことが出
来る ${ }^{20)}$ 。 LBC 系および YBC 系希土類材料の薄膜化の 基本形成プロセスは, 研究室的にはほぼ確立されるとと

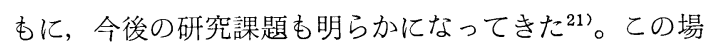
合, 特に留意された点は, LBC 系では, La サイトの $\mathrm{Ba}$ による置換, $\mathrm{YBC}$ 系では酸素欠損濃度の調整と超 伝導オルソ相の固定にあった。

$\mathrm{Bi}, \mathrm{Tl}$ 系非希土類材料では, Table 1 にも示すごと く, 化学組成比によって超伝導特性が異なり, しかもこ れらの各超伝導相が通常の熱平衡的な合成プロセスでは 混在して生成され易い22)。乙のような事情から, 非希土 類材料固有の問題を考慮した薄膜化プロセスが必要とさ れたが，まだ完成されたものではない。

ここでは, 希土類系材料の薄膜化基本プロセスと関連 させて, 非希土類系材料の薄膜化基本プロセスと最近の 薄膜化研究動向の一端を Bi 系材料を中心に解説する。 
Table 1 High- $T_{\text {c }}$ superconductors.

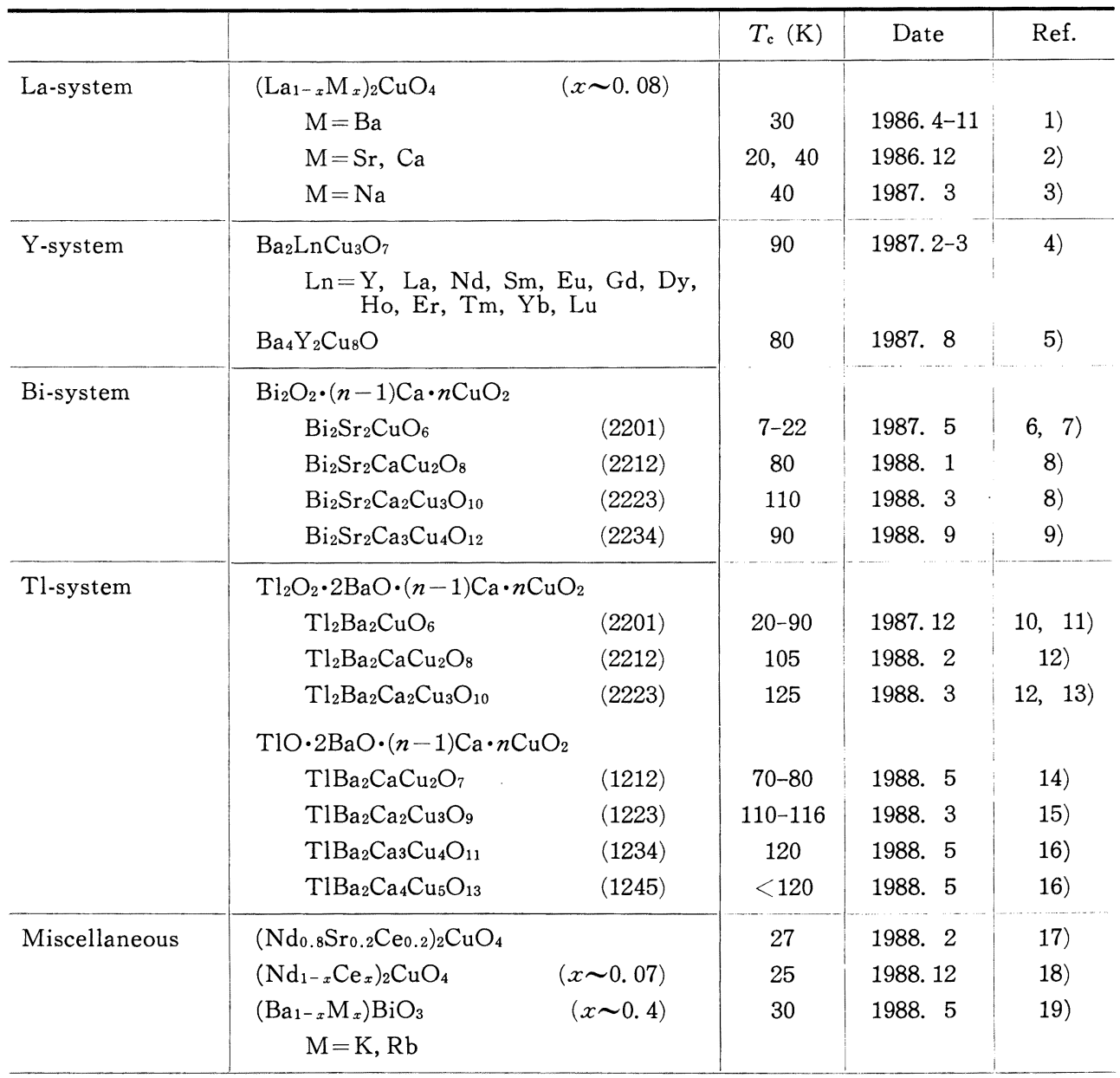

\section{2. 薄膜化基本プロセス}

\subsection{YBC 系}

YBC 系の薄膜化プロセスは，Table 2 のごとく 3 種 類に分けられる ${ }^{23)}$ 。すなわち，

プロセス (1) 結晶化温度*以下の 基板温度で 蒸着し た非晶質薄膜を熱処理し，結晶化と酸 素欠損濃度の調整を行う。

プロセス (2) 結晶化温度以上の基板温度で蒸着した 結晶質薄膜を熱処理し，酸素欠損濃度 の調整を行う。

プロセス ( 3 ) 結晶化温度以上の基板温度で蒸着する とともに，蒸着中に酸素欠損濃度の調 整をすませる。

\footnotetext{
とこでいう結晶化温度は, 蒸着時に結晶性の薄膜が形成さ れるための最低基板温度を意味する。非晶質を熱平衡状態 で加熱し, 結晶質に変化させるに必要な, 通常定義されて いる結晶化温度とは, 㛜密には異っている。
}

この場合, 蒸着は Fig. 1 亿示すような, 電子ビー $ム^{24)}$, レーザビーム ${ }^{25)}$, スパッタ ${ }^{26)}, \mathrm{CVD}^{27)}$ などの各 種の方式が提案されている。乙れまでの研究によると， YBC 系の薄膜化プロセスは, 酸素濃度の調整が付加さ れること以外は, ペロブスカイト構造強誘電体の薄膜化 と同様であることが確認された。すなわち，この種の高 温超伝導体は，酸素濃度により，超伝導を示すオルソ相 と半導体的なテトラ相が存在し，大気中では 700 800 ${ }^{\circ} \mathrm{C}$ 以上の高温領域にテトラ相, $600 \sim 700^{\circ} \mathrm{C}$ の低温領域 にオルソ相が存在する。このため, プロセス (1), (2) では, $600 \sim 700^{\circ} \mathrm{C}$ 以下の熱処理過程と超伝導を示すオ ルソ相の固定が必要であるととが，バルクおよび薄膜に おいて確認された ${ }^{28,29) 。 ~}$

このような基本形成プロセスの考察から，プロセス (2)において, $500 \sim 600^{\circ} \mathrm{C}$ で蒸着した結晶膜を，セラ ミックスで用いられる $900^{\circ} \mathrm{C}$ 前後の高温熱処理を用いず に, 蒸着温度より低い $400^{\circ} \mathrm{C}$ 程度の熱処理するという, 
Table 2 Fabrication processes for the high- $T_{\mathrm{c}}$ superconducting ceramics and thin films.

\begin{tabular}{|c|c|c|c|c|}
\hline & & $\begin{array}{l}\text { Chemical } \\
\text { composition }\end{array}$ & Crystallization & $\begin{array}{l}\text { Oxygen vacancy and/or } \\
\text { structural control }\end{array}$ \\
\hline \multicolumn{2}{|c|}{ Ceramics } & \multirow{2}{*}{$\begin{array}{c}\text { Mixing } \\
\text { Deposition } \\
\left(T_{\mathrm{s}}<T_{\mathrm{cr}}\right)\end{array}$} & \multirow{2}{*}{$\begin{array}{c}\text { Sintering } \\
\left(850-950^{\circ} \mathrm{C}\right) \\
\text { Annealing } \\
\left(850-950^{\circ} \mathrm{C}\right)\end{array}$} & $\begin{array}{l}\text { Annealing* } \\
\left(850-950^{\circ} \mathrm{C}\right)\end{array}$ \\
\hline \multirow{3}{*}{ Thin films } & 1 & & & $\begin{array}{l}\text { Annealing* } \\
\left(850-950^{\circ} \mathrm{C}\right)\end{array}$ \\
\hline & 2 & \multicolumn{2}{|c|}{$\begin{array}{l}\text { Deposition } \\
\left(T_{\mathbf{s}}>T_{\mathrm{cr}}\right)\end{array}$} & $\begin{array}{l}\text { Annealing* } \\
\left(400-950^{\circ} \mathrm{C}\right)\end{array}$ \\
\hline & 3 & \multicolumn{3}{|c|}{$\begin{array}{l}\text { Deposition** } \\
\left(T_{\mathrm{s}}>T_{\mathrm{cr}}\right)\end{array}$} \\
\hline \multicolumn{4}{|c|}{$\begin{array}{l}T_{\mathrm{s}}: \text { substrate temperature during deposition } \\
T_{\mathrm{cr}}: \text { crystallizing temperature }\left(500-700^{\circ} \mathrm{C}\right)\end{array}$} & $\begin{array}{l}\text { slow cooling } \\
\text { quenching }\end{array}$ \\
\hline
\end{tabular}

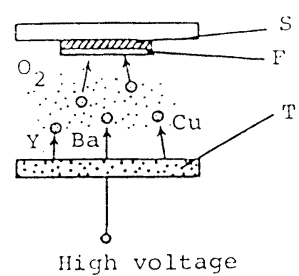

(a)

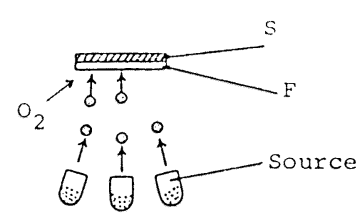

(b)

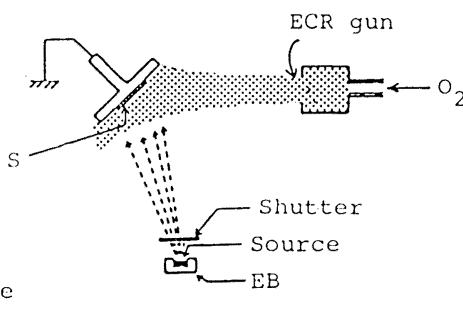

(d)
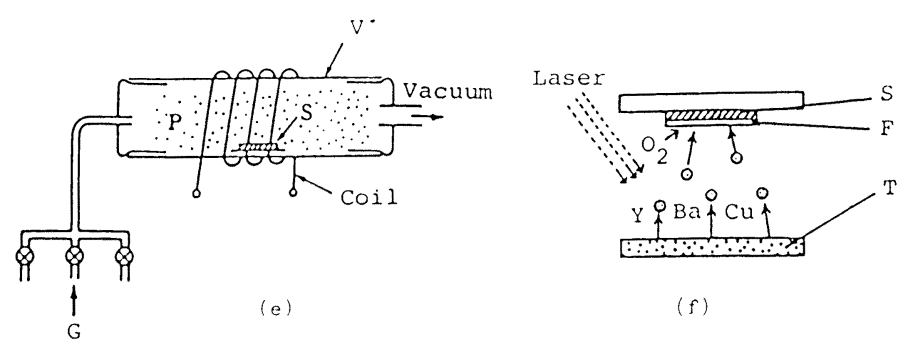

(f)

Fig. 1 Typical deposition systems for the high- $T_{\mathrm{c}}$ superconductors; (a) sputtering, (b) reactive evaporation, (c) activated reactive evaporation, (d) ion assisted evaporation, (e) plasma CVD, (f) reactive laser abrasion.

$\mathrm{S}$ : substrate, $\mathrm{F}:$ thin film, $\mathrm{T}$ : target, ES: evaporation source, $\mathrm{V}:$ vac. chamber, $\mathrm{EB}$ : electron beam, $\mathrm{G}$ : reactive gas source. 
いわゆる低温プロセスが最近確立されるに至った。

一方, 熱処理なしで形成するプロセス (3)は, in situ deposition といわれ, ここでは蒸着中にオルソ相が形成 されている必要がある。熱平衡状態では, 減圧下でしか もペロブスカイト構造薄膜の結晶化温度 $500 \sim 700^{\circ} \mathrm{C}$ に おいては，テトラ相が安定で超伝導オルソ相は存在しな (30)。したがって, MBE のような熱平衡的な真空蒸着 プロセスでは, in situ deposition は実現し得ない。し かし，乙れにイオン照射を付加した，いわゆる ion assisted deposition あるいはスパッタなどのプラズマ中 での薄膜形成では, 非熱平衡的な状態で薄膜が形成され るので, オルソ相を蒸着中に固定し, in situ deposition
を実現することは可能であろう。このような推察を実証 すべく, 酸素プラズマ中でのスパッタ蒸着で, in situ deposition が可能であるととが確認されたが31), 現在テ トラ相の混在, 結晶の不完全性などの問題が残ってお り，例えば高温において大きい臨界電流は望めない。乙 のような事情から, 現時点では, 完全な in situ deposition は実現されていないと思われる。in situ deposition と関連させて, 非熱平衡状態におけるオルソ相の安 定化の詳細は, 今後の研究課題であろう。

\section{$2.2 \mathrm{Bi}$ 系}

$\mathrm{Bi}$ 系の薄膜化基本プロセスも，基本的には Table 2 の $\mathrm{YBC}$ 系と同様, プロセス (1)，（2），(3)の 3 種類

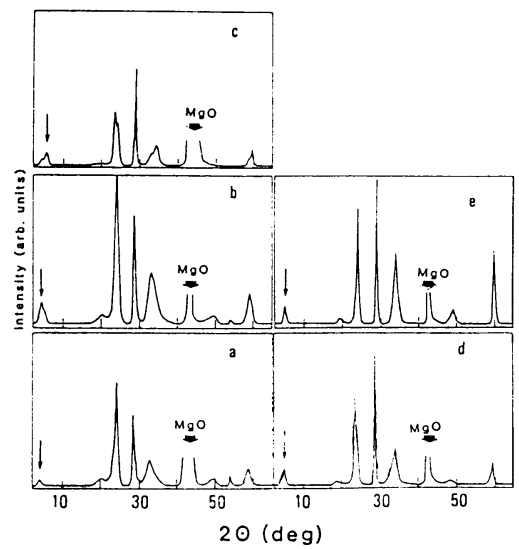

$X$-ray diffraction patterns over the $2 \theta$ range from $2^{\circ}$ to $65^{\circ}$ for samples a, b, c, d, and e. The arrow represents the (002)reflection.

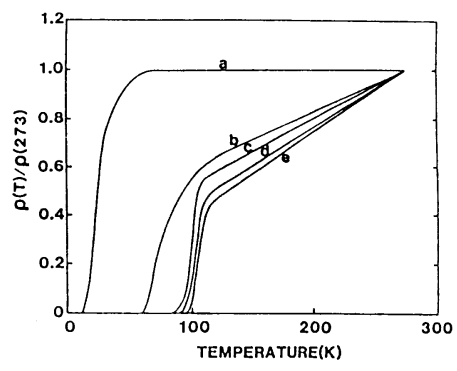

Normalized resistance vs temperature curves for samples a to e.

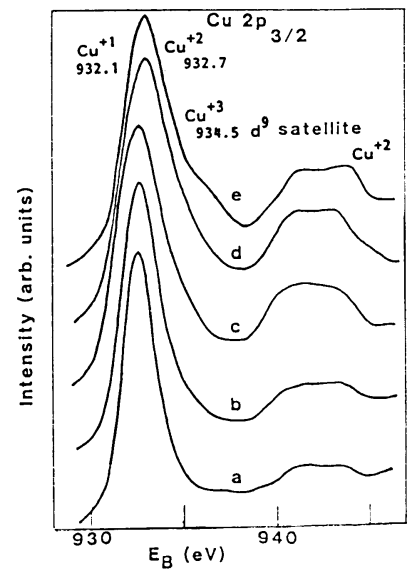

The $\mathrm{Cu} 2 \mathrm{p}_{3 / 2}$ electron spectra of samples $a, 3 f, c, d$, and $e$.
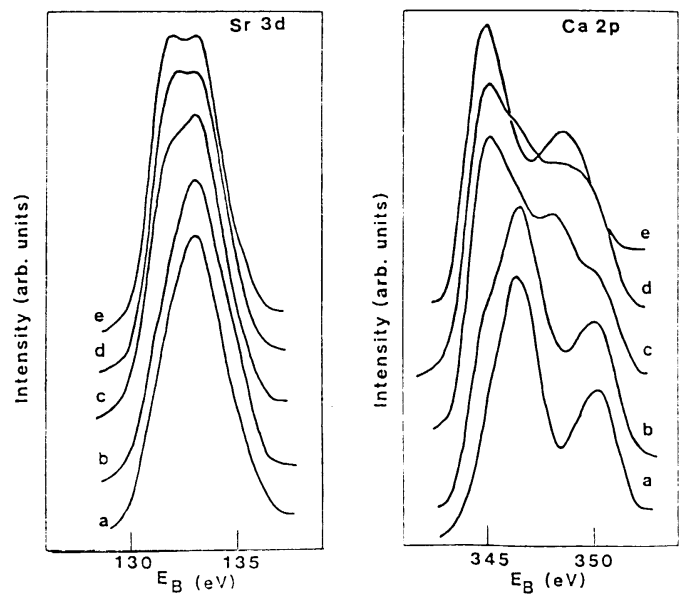

The Sr 3d electron spectra of The Ca 2p electron spectra of samples a, b, c, d, and e.
The Ca 2 p electron spectra
samples a, b, c, d, and e.

Fig. 2 Annealing effects on the structure and superconducting properties of sputtered thin films of Bi-system; (a ) as sputtered; (b ) annealed in $\mathrm{O}_{2}$ at $845^{\circ} \mathrm{C}, 12 \mathrm{~min}$; (c ) at $845^{\circ} \mathrm{C}$, $60 \mathrm{~min}$; (d) at $845^{\circ} \mathrm{C}, 300 \mathrm{~min}$; (e ) at $900^{\circ} \mathrm{C}, 20 \mathrm{~min} / 865^{\circ} \mathrm{C}, 300 \mathrm{~min}$. 
Table 3 Deposition process and superconducting properties of high- $T_{\mathrm{c}}$ superconducting thin films.

\begin{tabular}{|c|c|c|c|c|c|c|c|c|}
\hline \multirow{2}{*}{ Materials } & \multirow{2}{*}{$\begin{array}{l}\text { Struc- } \\
\text { ture* }\end{array}$} & \multirow{2}{*}{$\begin{array}{l}\text { Dep. } \\
\text { method** }\end{array}$} & \multirow{2}{*}{ Substrate } & \multicolumn{3}{|c|}{ Dep. conditions } & \multirow{2}{*}{ Film properties } & \multirow{2}{*}{ Ref. } \\
\hline & & & & $\begin{array}{c}\text { Sub. temp. } \\
\left({ }^{\circ} \mathrm{C}\right)\end{array}$ & Dep. rate & Miscellanea & & \\
\hline \multirow{8}{*}{$\begin{array}{l}\mathrm{BSCC} \\
\mathrm{Bi}-\mathrm{Sr}-\mathrm{Ca}- \\
\mathrm{Cu}-\mathrm{O}\end{array}$} & $\mathrm{PC}$ & MSP & $\begin{array}{c}(100) \\
\mathrm{MgO} \\
(100) \\
\mathrm{SrTiO}_{3}\end{array}$ & 700 & $\begin{array}{c}0.48 \\
\mu \mathrm{m} / \mathrm{hr}\end{array}$ & $\begin{array}{l}\text { Anneal in } \mathrm{O}_{2} \\
800 \sim 900^{\circ} \mathrm{C}\end{array}$ & $\begin{array}{l}T_{\mathrm{c}} \simeq 115 \mathrm{~K} \\
T_{\mathrm{R}=0} \simeq 104 \mathrm{~K} \\
\rho=50 \mu \Omega \mathrm{cm} \quad\left(T_{\mathrm{c}}\right) \\
J_{\mathrm{c}}>20 \times 10^{4} \mathrm{~A} / \mathrm{cm}^{2} \\
\quad(0 \text { tesla }, \quad 77 \mathrm{~K})\end{array}$ & 33) \\
\hline & $\mathrm{PC}$ & $\begin{array}{l}\text { MSP } \\
\text { co- } \\
\text { sputter }\end{array}$ & $\begin{array}{l}(100) \\
\mathrm{MgO}\end{array}$ & $\sim R T$ & $\begin{array}{c}\text { Thickness : } \\
0.4 \mu \mathrm{m}\end{array}$ & $\begin{array}{l}\text { Target: } \\
\mathrm{Bi}, \mathrm{SrCa}, \mathrm{Cu} \\
\text { Anneal in } \mathrm{O}_{2} \\
865^{\circ} \mathrm{C}\end{array}$ & $\begin{array}{l}\text { c-axis orientation } \\
T_{\mathrm{R}=0} \sim 80 \mathrm{~K} \\
B_{\mathrm{c} 2} \sim 8.5 \mathrm{~T} / \mathrm{K} \\
B_{\mathrm{c} 2} \sim 0.56 \mathrm{~T} / \mathrm{K}\end{array}$ & $34)$ \\
\hline & $\mathrm{PC}$ & EB & $\begin{array}{l}(100) \\
\mathrm{MgO}\end{array}$ & $\sim R T$ & $\begin{array}{c}\text { Thickness: } \\
0.2 \mu \mathrm{m}\end{array}$ & $\begin{array}{l}\text { Source: } \\
\mathrm{Bi}, \quad \mathrm{SrF} \\
\mathrm{CaF}_{2}, \quad \mathrm{Cu} \\
\text { Anneal in } \mathrm{O}_{2} \\
860 \sim 890^{\circ} \mathrm{C}\end{array}$ & $\begin{array}{l}\text { c-axis orientation } \\
c=30.605 \AA \\
T_{\mathrm{c}} \sim 110 \mathrm{~K} \\
T_{\mathrm{R}=0} \sim 60 \mathrm{~K}\end{array}$ & $35)$ \\
\hline & $\mathrm{PC}$ & EB & $\begin{array}{c}(110) \\
(100) \\
\mathrm{SrTiO}_{3}\end{array}$ & $\sim R T$ & $\begin{array}{l}\text { Thickness : } \\
0.3 \sim 0.5 \mu \mathrm{m}\end{array}$ & $\begin{array}{l}\text { Source: } \\
\mathrm{Bi}, \mathrm{SrF}_{2}, \\
\mathrm{CaF}_{2}, \mathrm{Cu} \\
\text { Anneal in } \\
\text { wet } \mathrm{O}_{2} \\
850^{\circ} \mathrm{C}, 5 \mathrm{~min}\end{array}$ & $\begin{array}{l}\text { c-axis orientation, } \\
\text { epitaxial } \\
T_{\mathrm{R}=0} \sim 80 \mathrm{~K} \\
J_{\mathrm{c}}=1 \times 10^{6} \mathrm{~A} / \mathrm{cm}^{2} \\
\quad(0 \text { tesla, } 4.2 \mathrm{~K}) \\
\rho \simeq 150 \mu \Omega \mathrm{cm}\left(T_{\mathrm{c} 0}\right)\end{array}$ & 36) \\
\hline & $\mathrm{PC}$ & $\begin{array}{l}\text { LA } \\
(\text { ArF } \\
\text { eximer } \\
\text { laser) }\end{array}$ & $\begin{array}{l}(100) \\
\mathrm{MgO}\end{array}$ & $R T$ & $\begin{array}{l}\text { Thickness : } \\
0.1 \sim 2 \mu \mathrm{m}\end{array}$ & $\begin{array}{l}\text { Target BSCCO } \\
\text { eximer laser, } \\
10 \mathrm{~J} / \mathrm{cm}^{2} \text {. } \\
\text { Anneal in } \\
\text { air, } 890^{\circ} \mathrm{C} \\
1 \mathrm{~min} .\end{array}$ & $\begin{array}{l}\text { c-axis orientation } \\
T_{\mathrm{c}} \sim 80 \mathrm{~K}(c=30.8 \AA) \\
T_{\mathrm{c}} \sim 120 \mathrm{~K}(c=36.8 \mathrm{~A})\end{array}$ & 37) \\
\hline & $\mathrm{PC}$ & IBS & $\begin{array}{l}(100) \\
\mathrm{MgO} \\
\mathrm{ZrO}_{2}\end{array}$ & $\sim R T$ & $\begin{array}{l}\text { Thickness : } \\
0.3 \sim 1 \mu \mathrm{m}\end{array}$ & $\begin{array}{c}\text { Anneal in } \mathrm{O}_{2} \\
825-880^{\circ} \mathrm{C}\end{array}$ & $\begin{array}{l}\mathrm{Bi}_{2.00} \mathrm{Sr}_{2.09} \mathrm{Ca}_{0.75^{-}} \\
\mathrm{Cu}_{2.44} \mathrm{O}_{x}, \\
T_{\mathrm{c}} \sim 85 \mathrm{~K}, \\
T_{\mathrm{R}=0} \sim 75 \mathrm{~K} \\
\mathrm{Bi}_{4.00 \mathrm{Sr}_{3.12} \mathrm{Ca}_{3.03}-} \\
\mathrm{Cu}_{4.56} \mathrm{O}_{x}, \\
T_{\mathrm{c}} \sim 110 \mathrm{~K}, \\
T_{\mathrm{R}=0} \sim 63-67 \mathrm{~K}\end{array}$ & 38) \\
\hline & $\mathrm{PC}$ & $\begin{array}{l}\text { MSP } \\
\text { layer- } \\
\text { by- } \\
\text { layer } \\
\text { dep. } \\
\text { multi- } \\
\text { target }\end{array}$ & $\begin{array}{l}(100) \\
\mathrm{MgO}\end{array}$ & $650^{\circ} \mathrm{C}$ & $\begin{array}{l}\sim 100 \AA / \text { hr } \\
\text { Thickness : } \\
200-400 \AA\end{array}$ & $\begin{array}{l}\text { Target : } \\
\mathrm{Bi}, \mathrm{SrCu}, \\
\mathrm{CaCu} \\
\text { Anneal in } \mathrm{O}_{2} \\
855^{\circ} \mathrm{C}, 5 \mathrm{hr} .\end{array}$ & $\begin{array}{r}\text { c-axis orientation } \\
\mathrm{Bi}_{2} \mathrm{Sr}_{2} \mathrm{Ca}_{1} \mathrm{Cu}_{2} \mathrm{O}_{x} \\
T_{\mathrm{c} 0 \sim 80 \mathrm{~K}} \sim 80 \\
\mathrm{Bi}_{2} \mathrm{Sr}_{2} \mathrm{Ca}_{2} \mathrm{Cu}_{3} \mathrm{O}_{x} \\
T_{\mathrm{c} 0} \sim 110 \mathrm{~K} \\
\mathrm{Bi}_{2} \mathrm{Sr}_{2} \mathrm{Ca}_{3} \mathrm{Cu}_{4} \mathrm{O}_{x} \\
T_{\mathrm{c} 0} \sim 90 \mathrm{~K}\end{array}$ & 9) \\
\hline & $\mathrm{PC}$ & CVD & $\begin{array}{l}(100) \\
\mathrm{MgO}\end{array}$ & $910^{\circ} \mathrm{C}$ & $\begin{array}{c}8 \mu \mathrm{m} / \mathrm{hr} \\
\text { Thickness : } \\
8 \mu \mathrm{m}\end{array}$ & $\begin{array}{l}\text { Source: } \\
\text { bismuth } \\
\text { alkoxide, } \\
\beta \text {-diketonate } \\
\text { chelates of } \\
\mathrm{Sr}, \mathrm{Ca}, \mathrm{Cu} \text {. }\end{array}$ & $\begin{array}{l}\text { c-axis orientation, } \\
T_{\mathrm{R}=0} \sim 78 \mathrm{~K}\end{array}$ & 39) \\
\hline
\end{tabular}

* PC : polycrystal

** MSP : magnetron sputter, EB : electron beam 
に分けられる ${ }^{23)}$ 。 Bi 系が発見された当初, YBC 系で用 いられる酸素濃度調整のための熱処理過程の必要性が疑 問視されたが, 結晶性の as-deposite 膜を酸素中熱処理 することにより, 超伝導転移温度や零抵抗温度の上昇が 認められることが YBC 系のプロセス (1), (2)と同様 に, 熱処理は必要であることがわかっていた。しかし, 熱処理の効果は YBC 系のような酸素濃度を調整するよ り屯, むしろ LBC 系において 2 価の $\mathrm{Ba}$ で 3 価の $\mathrm{La}$ を置換し，ホールを供給するのと同様に, $\mathrm{Bi}^{+3}$ の一部 を $\mathrm{Sr}^{+2}$ で置換し，ホールを注入する作用をするとも考 えられている22)。

しかしながら，ホールの注入の機構の詳細は, 議論の 対象となる超伝導のサンプルの作成状態によっても異な るようである。その一例として，スパッタ膜の熱処理に おける特性変化を Fig. 2 に示す ${ }^{32)}$ 。同図のスパッ夕膜 は, (100) $\mathrm{MgO}$ 基板に, $800^{\circ} \mathrm{C}$ の基板温度でスパッタ 蒸着した $\mathrm{c}$ 軸配向膜で, 組成は $\mathrm{Bi}_{2} \mathrm{Sr}_{2} \mathrm{Ca}_{2} \mathrm{Cu}_{3} \mathrm{O}_{x}$ であ る。この種のスパッタ膜は, as-sputter 膜で超伝導を示 すが,一般には, 超伝導転移に急峻さはなく, 超伝導転 移温度，零抵抗温度は熱処理膜より低い。Fig. 2 には， 熱処理前後における, X線回折スペクトル, 超伝導 $\rho-T$ 特性の変化とXPS による $\mathrm{Cu}, \mathrm{Sr}, \mathrm{Ca}$ の電子状態の変 化とを対比させている。

Fig. 2 が示すごとく, 熱処理によって結晶性が改善 され，同時に超伝導の転移もバルク上ほぼ同様になる。 このような変化と対応して, $\mathrm{Cu}$ の価数が増加し, 熱処 理前では $\mathrm{Cu}^{+1}$ と $\mathrm{Cu}^{+2}$ であったのが, 熱処理により $\mathrm{Cu}^{+2}$ と $\mathrm{Cu}^{+3}$ に変化する様相が, $\mathrm{Cu} 2 \mathrm{p}_{3 / 2}$ の XPS ス ペクトルから推察される。一方, $\mathrm{Bi}, \mathrm{Sr}, \mathrm{Ca}$ の電子状 態は, Bi については, 熱処理に対しても変化しないが, Sr, Ca サイトは顕著に変化することが Fig. 2 の Sr 3d, Ca 2 p の XPS スペクトルからうかがえる。“この事実 は, 熱処理過程で $\mathrm{Sr}, \mathrm{Ca}$ サイトのオーダリングの変化 が発生し，この変化によりホールが注入されるとも考え られるが, 詳細は今後の研究課題でもある。

また，YBC 系と異なる点として，YBC 系で問題に なった酸素濃度によるテトラ相/オルソ相の出現がない 代りに, Table 1 で示すような化学組成比の異った化合 物が, 熱平衡プロセスでは, ほぼ同一形成条件で生成 し, 例えば $110 \mathrm{~K}$ 級高温超伝導相, $\mathrm{Bi}_{2} \mathrm{Sr}_{2} \mathrm{Ca}_{2} \mathrm{Cu}_{3} \mathrm{O}_{x}$ の 単相化が困難である事があげられる。

Table 3 に, Bi 系薄膜の代表的な形成法と形成条件 を示す ${ }^{33-59)}$ 。形成法は, Fig. 1 亿示した希土類系と同様 である。この場合，基本的にはセラミックス合成と類似 の熱平衡的プロセスであるプロセス(1)では，セラミッ クスと同様に，低温超伝導相といわれている $80 \mathrm{~K}$ 級の
$\mathrm{Bi}_{2} \mathrm{Sr}_{2} \mathrm{Ca}_{2} \mathrm{Cu}_{2} \mathrm{O}_{x}$ が得られるが, $110 \mathrm{~K}$ 級の高温相は得 られない。

なお，乙れらの薄膜形成のための基板として，YBC 系と同様に, $\mathrm{MgO}, \mathrm{SrTiO}_{3}, \mathrm{Si}$ 等の単結晶が用いられ る。乙の場合, YBC 系と同様に基板之薄膜との界面に おける相互拡散が, 熱処理プロセスで発生するため, $\mathrm{ZrO}_{x}$ 系のバッファ層屯提案されているが40), バッファ 層の必要性は基板表面状況と薄膜の結晶性, 界面状況に よっても変化することが知られている ${ }^{411}$ 。

\section{Bi 系薄膜の合成と物性}

\section{$3.1 \mathrm{Bi}$ 系薄膜の合成}

熱平衡プロセス類似のプロセス (1)では, セラミック スと同様, $\mathrm{Bi}_{2} \mathrm{Sr}_{2} \mathrm{Ca}_{1} \mathrm{Cu}_{2} \mathrm{O}_{x}$ の低温相が安尘に存在す る。この理由として, Table 3 にも示されているように, 熱処理過程において 850 $900^{\circ} \mathrm{C}$ という融点に近い温度 で処理するため, 薄膜は熱処理中に融解し，乙れが室温 まで冷却される途中に， $800^{\circ} \mathrm{C}$ 以下で安等といわれる低 温相が固定されることが考えられる。したがって, 蒸着 膜の化学組成が熱処理前高温相 $\mathrm{Bi}_{2} \mathrm{Sr}_{2} \mathrm{Ca}_{2} \mathrm{Cu}_{3} \mathrm{O}_{x}$ に相当 していても, 熱処理後は低温相に変化する。また, 低温 相以外の中間化合物屯析出する。

一方, 高温相の安定領域は, 低温相より高い温度領域 にあるといわれている。祥細は明らかでないが, 蒸着と いう非熱平衡的プロセスで, 蒸着中の基板温度を高め ると高温相が凍結される叮能性がある。このような推察 は, スパッ夕蒸着で確認された。Fig. 3 は, その代表 的な結果を示す。すなわち, 蒸着中の基板温度を変えて Bi 系の薄膜を形成すると, 與味あることに, 基板温度 の低いプロセス (1)では低温相しか形成されないが, 基 板温度の高いプロセス $(2)$ では, 高温相が形成される。 この場合 $800^{\circ} \mathrm{C}$ 以上の基板温度では, 単一相に相当す る高温相薄膜が得られる。これは, 高温相は $800^{\circ} \mathrm{C}$ 以 上の比較的高い温度に安定域があり，乙の安定域で生成 された高温相が室温にまで涷結された事を小す。この超 伝導転移温度は $110 \mathrm{~K}$, 笭抵抗温度は $104 \mathrm{~K}$ とバルクに 近い值を示す。

このようにして形成された Bi 系薄膜は, Fig. 2 のX 線回折スペクトルからもわかるように， c 軸配向してい る。またその䏒状は, マイカ状の大きな結晶から構成さ れている。c 面方向から TEM 像を撮ると, Fig. 4 に 示すごとく, 広範囲に均質である。しかしながら, 薄膜 の a-b 面方向をみると, Fig. 5 に亦すごとく, Cu-O の層数の異った, Bi-Sr-Ca-Cu-O 構造が intergrowth していることがわかる。この事尖は, Fig. 2 のX 線回 折の低角度の (002) ピークの袸に広がりがある事, ピー 


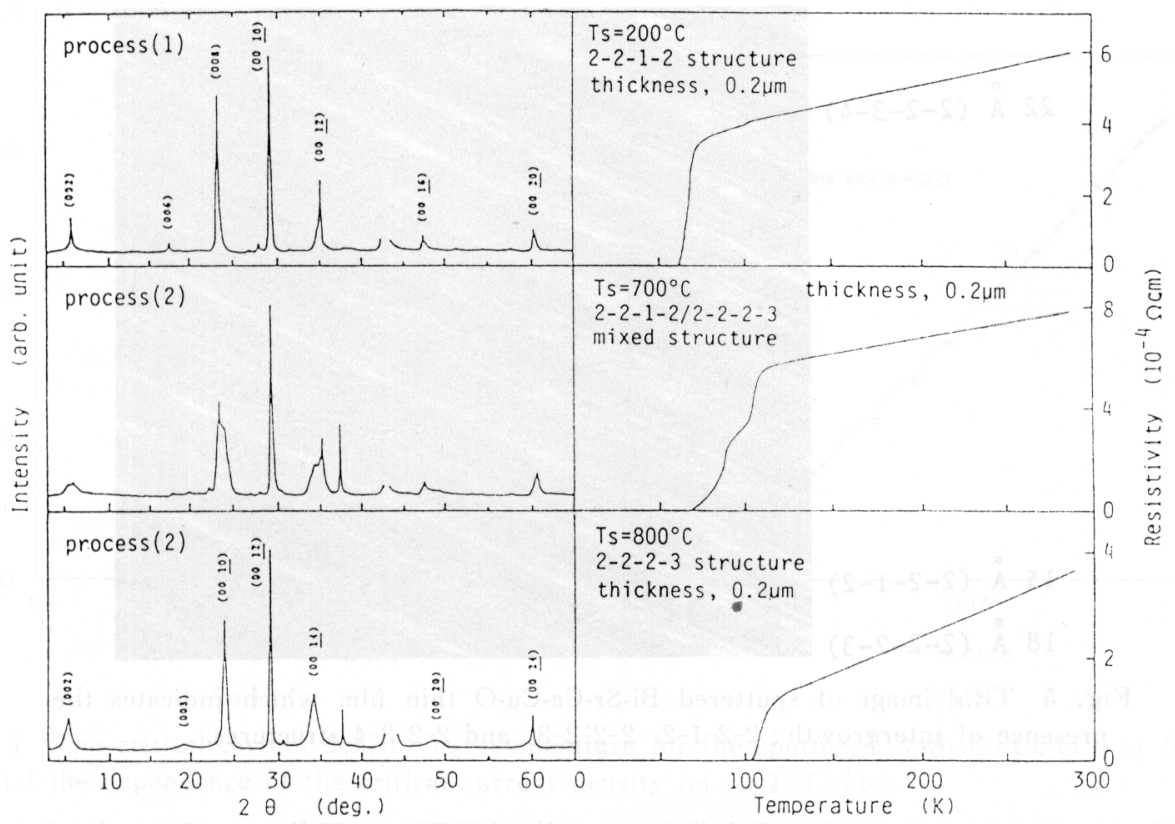

Fig. 3 X-ray diffraction patterns and resistivity vs. temperature characteristics for the $\mathrm{Bi}-\mathrm{Sr}-\mathrm{Ca}-\mathrm{Cu}-\mathrm{O}$ thin films sputtered at various substrate temperatures $T_{\mathrm{s}}$ : (100) $\mathrm{MgO}$ substrate, annealed at $850-900^{\circ} \mathrm{C}, 5 \mathrm{hr}$ in $\mathrm{O}_{2}$.
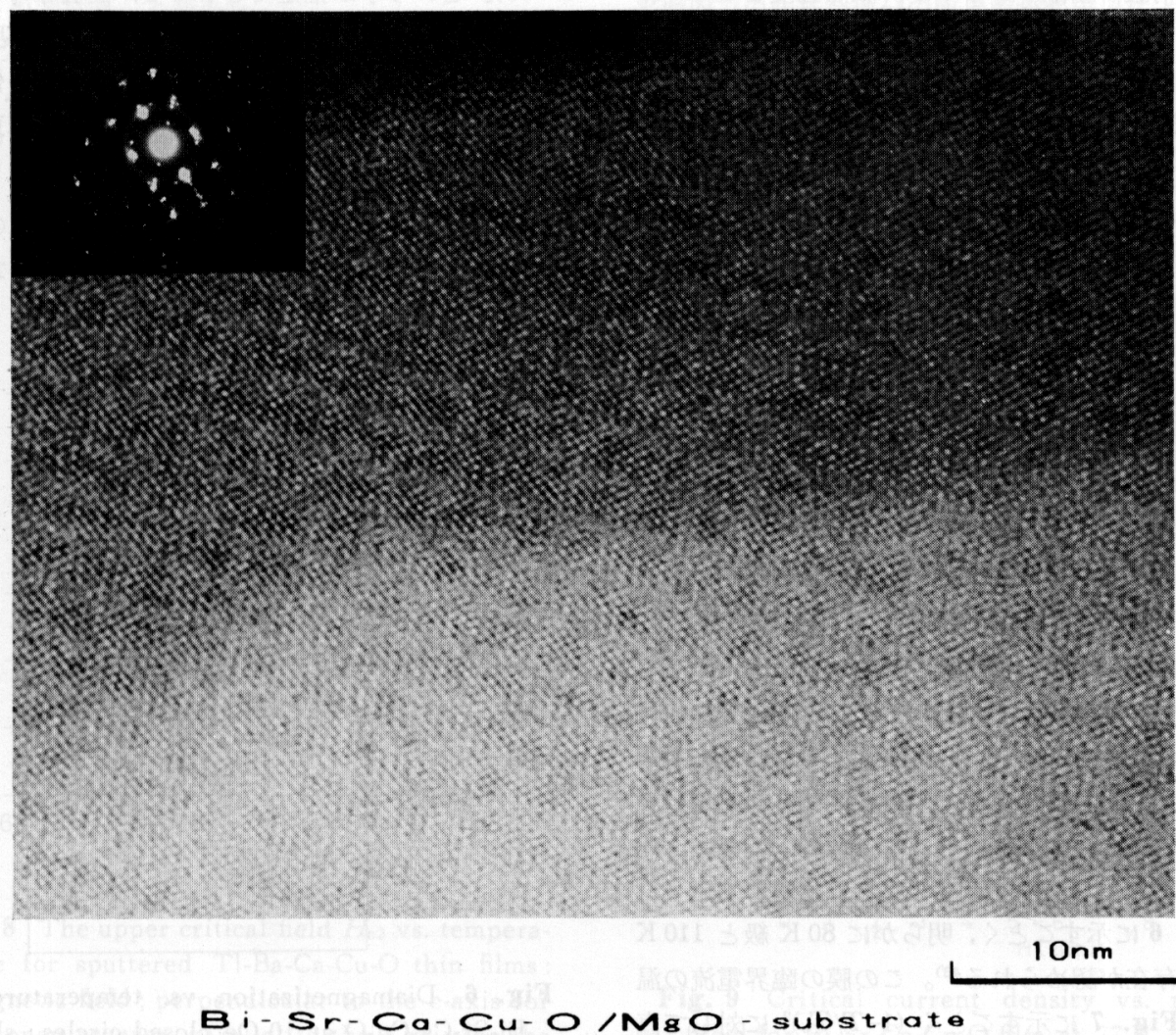

$10 \mathrm{~nm}$

Fig. 4 TEM image of the sputtered $\mathrm{Bi}-\mathrm{Sr}-\mathrm{Ca}-\mathrm{Cu}-\mathrm{O}$ thin film of $2-2-1-2$ structure. 


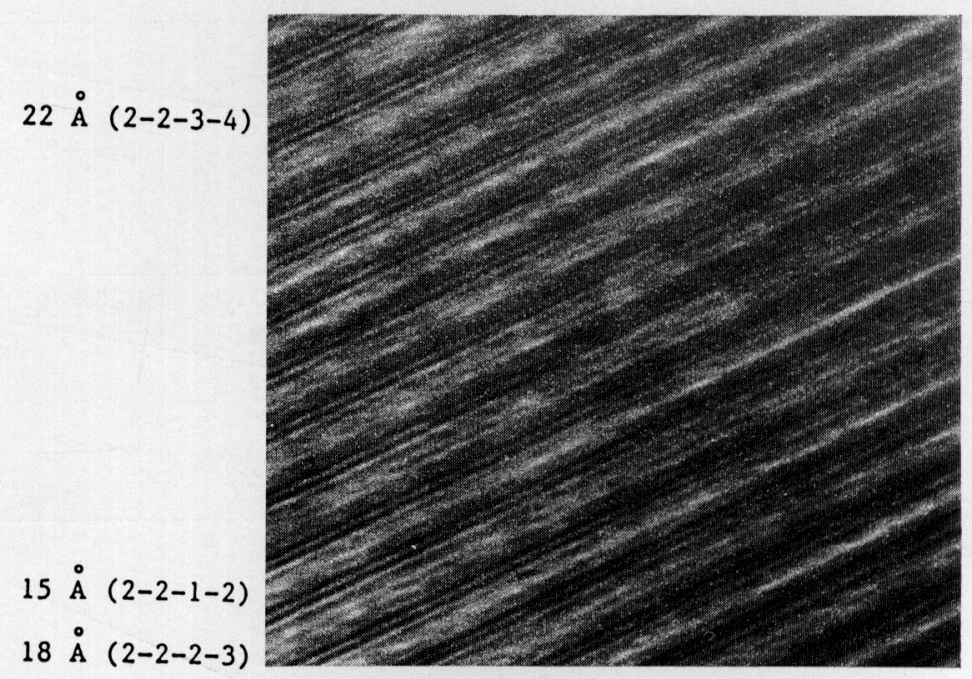

Fig. 5 TEM image of sputtered Bi-Sr-Ca-Cu-O thin film which indicates the presence of intergrowth; $2-2-1-2,2-2-2-3$, and $2-2-3-4$ structures.

クの位置が単一相よりシフトしている事からも推論さ れる。この intergrowth の状態の詳細は, X線回折ス ペクトルのシミュレーション実験より, $\mathrm{Cu}-\mathrm{O}$ 層の異な る $\mathrm{Bi}$ 層状構造の結晶ユニットが, 数層程度ずつ intergrowth している状態であることがほぼ明らかになっ た。また，高温相の存在率は，SQUID の測定から 5〜 10\% であることが推察された。

このような intergrowth は，プロセス(2)における 熱処理中に生成されるため, 熱処理を導入するかぎり, 高温相の完全単相化は一般に困難である。ただ，プロセ ス(2)にお゙ては，蒸着時に高温相が不完全であるが形 成されているため，プロセス（1）のように熱処理後低温 相の単一相になることはない。このような事情があるた め, 熱処理条件を変化させた, 高温相の単相化の試みが 数多く行われているにもかかわらず，その実現は困難で ある ${ }^{42)}$ 。高温相の熱平衡プロセスにおける単相化は, 熱 処理条件の詳細な検討よりも, $\mathrm{Pb}$ 等の異種材料の導入 の方が有効である ${ }^{22)}$ 。

\section{$3.2 \mathrm{Bi}$ 系薄膜の超伝導特性}

$\mathrm{Bi}$ 系薄膜の比抵抗は，転移温度において，低い值は $50 \mu \Omega \mathrm{cm}, \quad \rho_{300} / \rho_{T_{\mathrm{c}}} \simeq 1.5 \sim 3$ の範囲にあるが，単一相の 完全な薄膜が得られていないため詳細は明らかでない。 この種の薄膜は, 超伝導相の異った構造が intergrowth することを示したが, rf-SQUID で反磁化率の測定を行 うと, Fig. 6 に示すごとく, 明らかに $80 \mathrm{~K}$ 級と $110 \mathrm{~K}$ 級の 2 相の存在が認められる ${ }^{43)}$ 。乙の膜の臨界電流の温 度変化は, Fig. 7 に示すごとく $\left(1-T / T_{\mathrm{c}}\right)^{2}$ に対して直 線関係にあり，層状構造固有の特性であろう ${ }^{44)}$ 。この場
合の臨界電流は, $77 \mathrm{~K}$ で〜 $10^{5} \mathrm{~A} / \mathrm{cm}^{2}$ であるが，との值 はほとんど高温相を流れている電流成分であろう。一 方, Fig. 6 の SQUID の特性から, 高温相の体積率が 5〜 10\% という事が推定できるので, 高温相の単相では $1 \sim 2 \times 10^{6} \mathrm{~A} / \mathrm{cm}^{2}$ の臨界電流が期待される。最近, $\mathrm{Bi}$ 系 で $1.9 \times 10^{6} \mathrm{~A} / \mathrm{cm}^{2}$ というほぼこの期待值に近い值が実測 されている ${ }^{45)}$ 。しかし，この種の薄膜には, 磁束緩和に

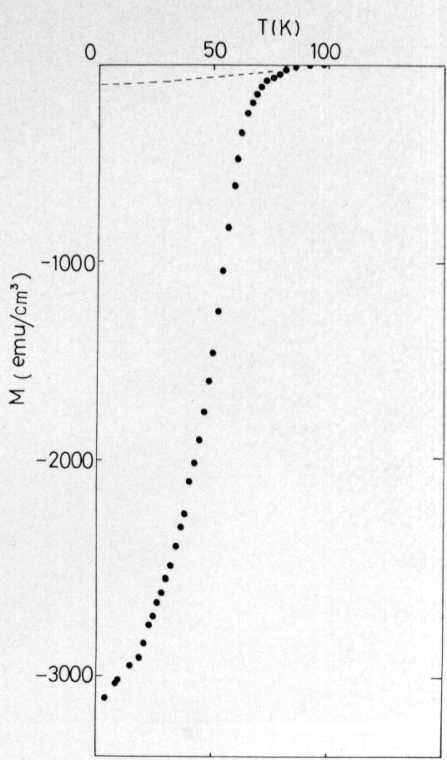

Fig. 6 Diamagnetization vs. temperature for $\mathrm{Bi}-\mathrm{Sr}-\mathrm{Ca}-\mathrm{Cu}-\mathrm{O}$ at $10 \mathrm{Oe}$ closed circles : shielding effect, dotted line: Meissner effect. 


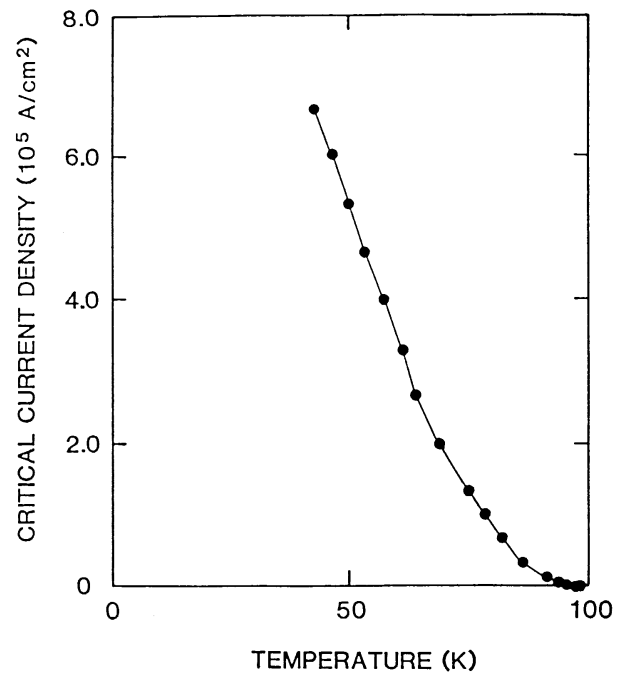

(a)

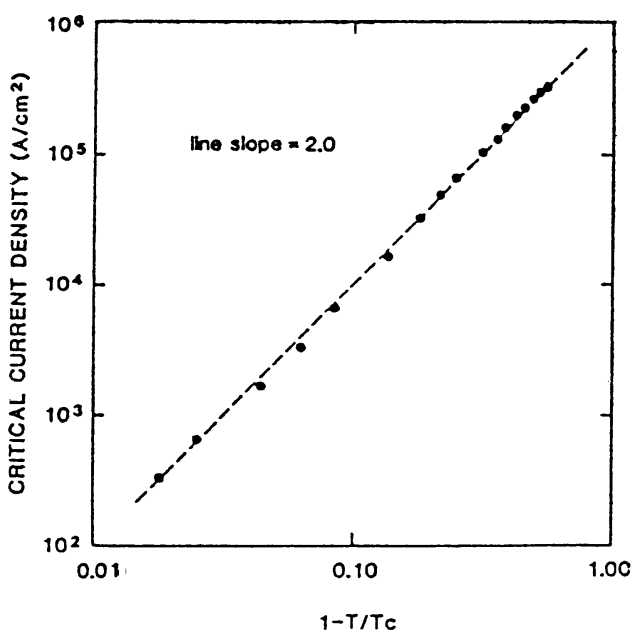

(b)

Fig. 7 The critical current density vs. temperature for the sputtered $\mathrm{Bi}-\mathrm{Sr}-\mathrm{Ca}-\mathrm{Cu}-\mathrm{O}$ thin film (a) and the dependence of the critical current density on $\left(1-T / T_{c}\right)(b)$.

起因したクリープ現象 ${ }^{46)}$, 膜厚方向の電流の不均一性の 存在などのため, 臨界電流の測定值は, 測定手法によっ て 1 〜 桁異なることがある。

$\mathrm{c}$ 軸配向したスパッ夕薄膜についての超伝導異方性 は, Fig. 8 に示す上部臨界磁界 $H_{\mathrm{C}_{2}}$ の測定から 15 程 度であり，この值は希土類系と $\mathrm{T} 1$ 系の間にある ${ }^{47) 。 乙 ~}$ の場合, $H_{\mathrm{C}_{2}}$ が $100 \mathrm{~T}$ 以上であることを考虑すると, この種の溥膜の臨界電流は $1 \mathrm{~T}$ 程度の磁界の印加では 変化しないはずであるが, 実際は Fig. 9 に示すごとく

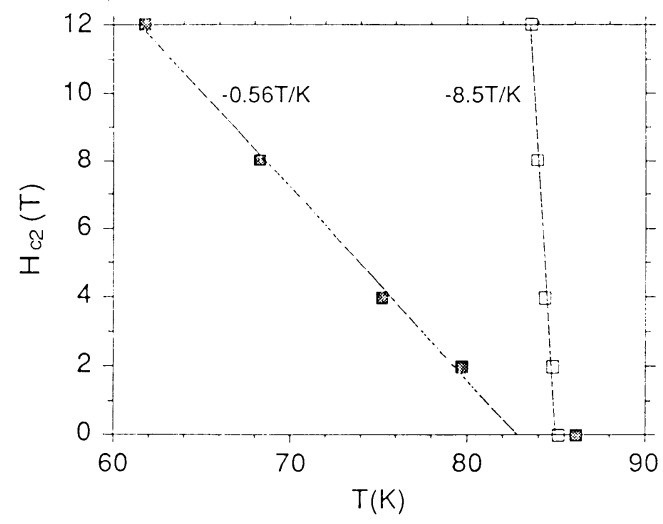

Fig. 8 The upper critical field $H_{\mathrm{c} 2}$ vs. temperature for sputtered $\mathrm{Tl}-\mathrm{Ba}-\mathrm{Ca}-\mathrm{Cu}-\mathrm{O}$ thin films : magnetic field; perpendicular to the c-axis for the open squares, parallel to the c-axis for the closed square.
磁界の印加によって顕著に変化する。これは, 超伝導体 の intrinsic な性質を示すむのではなく, むしろ 2 次元 平面内での弱結合部分の臨界電流が磁界によって大きく 依存している事を示している。

Table 4 は Bi 系薄膜の特性を整理したあのである。 これらの值の詳細は，良質の薄膜が形成されることによ り明らかにされる。

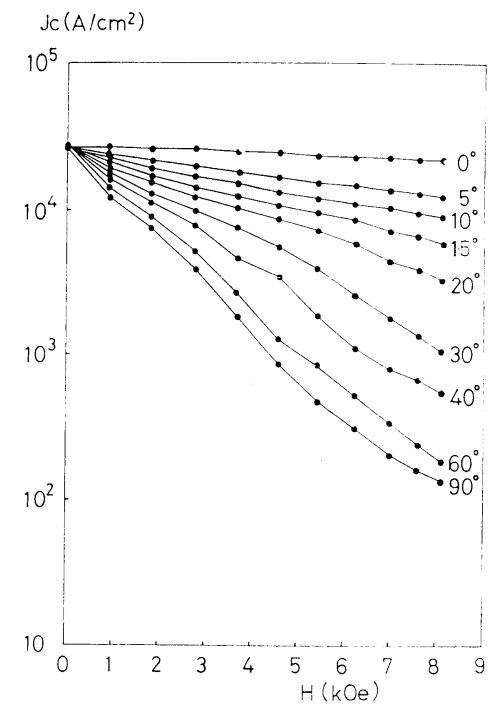

Fig. 9 Critical current density vs. magnetic fiield for $\mathrm{Bi}-\mathrm{Sr}-\mathrm{Ca}-\mathrm{Cu}-\mathrm{O}$ film at $77 \mathrm{~K}$, changing the field angle. 
Table 4 Typical superconducting properties of high- $T_{\mathrm{c}}$ superconductive thin films.

\begin{tabular}{l|c|c|c|c|cc}
\hline & $\begin{array}{c}\mathrm{La}_{1-x} \mathrm{Sr}_{x} \mathrm{CuO}_{4} \\
x=0.05\end{array}$ & $\mathrm{YBa}_{2} \mathrm{Cu}_{3} \mathrm{O}_{7-x}$ & \multicolumn{2}{|c|}{$\mathrm{Bi}-\mathrm{Sr}-\mathrm{Ca}-\mathrm{Cu}-\mathrm{O}$} & \multicolumn{2}{|c}{$\mathrm{Tl}-\mathrm{Ba}-\mathrm{Ca}-\mathrm{Cu}-\mathrm{O}$} \\
& 30 & 84 & 80 & 104 & 102 & 117 \\
\hline$T_{\mathrm{c}_{R=0}}(\mathrm{~K})$ & 6.3 & 4.6 & 7.3 & 7 & 20 & - \\
$-d H_{\mathrm{C} 2 \mu} / d T(\mathrm{~T} / \mathrm{K})$ & 1.2 & 0.54 & 0.36 & 0.34 & 0.6 & - \\
$-d H_{\mathrm{C} 2 \perp} / d T(\mathrm{~T} / \mathrm{K})$ & 130 & 373 & 440 & 500 & 1408 & - \\
$H_{\mathrm{C} 2 \mu}(0)(\mathrm{T})$ & 25 & 44 & 20 & 24 & 42 & - \\
$H_{\mathrm{C} 2 \perp}(0)(\mathrm{T})$ & 37 & 27 & 12.8 & 11.7 & 28 & - \\
$\xi_{\|}(\mathrm{A})$ & 7.1 & 3.2 & 2.7 & 2.6 & 0.8 & - \\
$\xi_{\perp}(\mathrm{A})$ & 5.3 & 8.4 & 20 & 20 & 31 & - \\
Anisotoropy & & & & &
\end{tabular}

\section{4. 原子層蒸着による超伝導相の制御}

一般に蒸着した膜を融点に近い温度で熱処理すると intergrowth 現象のため単相化されがたい。一方, 結晶 化温度程度に基板温度を保持して, 原子層スケールの精 度で, 目的とする化学組成の薄膜を非熱平衡的に形成す ると，任意の超伝導相が制御された状態で合成されるこ とが期待される。とのような考えに従い, $\mathrm{Bi}, \mathrm{SrCu}$ お よび $\mathrm{CaCu}$ ターゲットからなる多元スパッタ装置を用 いて，Fig. 10 亿示すような方式で， Bi 系の各構造の 単相化を試みると, 期待通り, 任意の $\mathrm{Cu}-\mathrm{O}$ 層数の薄 膜が形成されることが最近明らかになった9)。乙の場合， $\mathrm{Cu}-\mathrm{O}$ 層数は， $\mathrm{Ca}-\mathrm{Cu}-\mathrm{O}$ の蒸着量を変えるととにより 制御できる。原理的には，任意の $\mathrm{Cu}-\mathrm{O}$ 層数をむつ薄 膜が形成され得るが, 実験的には 1 層から 5 層までの $\mathrm{Cu}-\mathrm{O}$ 層で構成された $\mathrm{Bi}$ 層状ペロブスカイト構造の薄 膜の形成が確認された ${ }^{48}$ 。

乙の場合, 基板温度は $650^{\circ} \mathrm{C}$ 程度で, $\mathrm{X}$ 線回折スペ クトルから, スパッタ蒸着中に $\mathrm{Bi}$ 層状ペロフスカイト 構造の形成が確認されている。しかし, as-sputter 膜の 超伝導特性は, 熱処理膜のような急峻な超伝導転移が見 られず，零抵抗温度む10 30 K と低い。との as-sput- ter 膜の TEM 像には, 明膫な格子像が見られない点か ら, as-sputter 膜は結晶性が不完全であるとと, あるい はホールの注入が不充分であることがわかる。この assputter 膜は, プロセス (2)に従って, 熱処理すると超伝 導特性が改良される。Fig. 11 は, 熱処理した Bi 系薄 膜の特性を示す。乙れらは，原子首スケールで， $\mathrm{Cu}-\mathrm{O}$ 層数を 2 層から 4 層まで変化させたもので, 膜厚はそれ ぞれ 9 結晶ユニットである。その值は 300 400 凡 程 度である。同図において, $\mathrm{Cu}-\mathrm{O}$ 層数に刘応した $\mathrm{X}$ 線回 折スペクトルが見られる。また興味あることに，低角度 における(002) ピークの裙の広がりが狭い事から，通 常の蒸着で見られた intergrowth が少ない事がわかる。 なお，熱処理をしないプロセス（3)の研究は今後の課題 である。

このような原子層スケールでの蒸着制御は, 多元 ス パッタ以外でも可能で, $\mathrm{Bi}$ と $\mathrm{SrCaCuO}$ ターゲットを 用いた二元スパッタ49， $\mathrm{BiO}$ と $\mathrm{SrCaCuO}$ ターゲットを 用いた二元イオンビームスパッタ ${ }^{50)}, \mathrm{BiO}, \mathrm{SrCuO}$ と $\mathrm{CaCuO}$ ターゲットを用いたレーザ蒸着 ${ }^{51)}$ においても, この種の構造制御の可能性が確認された。しかし, これ らの方法では，X線構造的には原子層制御されている が, 超伝導特性改善のため, 熱処理を必要とする。この

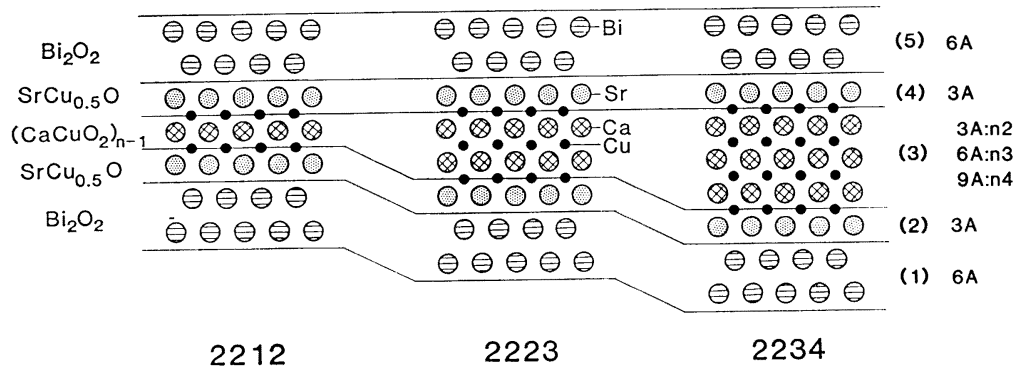

Fig. 10 Layer-by-layer deposition of $\mathrm{Bi}_{2} \mathrm{Sr}_{2} \mathrm{Ca}_{n}{ }_{n} \mathrm{Cu}_{n} \mathrm{O}_{x}$ by multi-target sputtering: alternate deposition in the order $(1) \rightarrow(2) \rightarrow(3) \rightarrow(4) \rightarrow(5)$. 


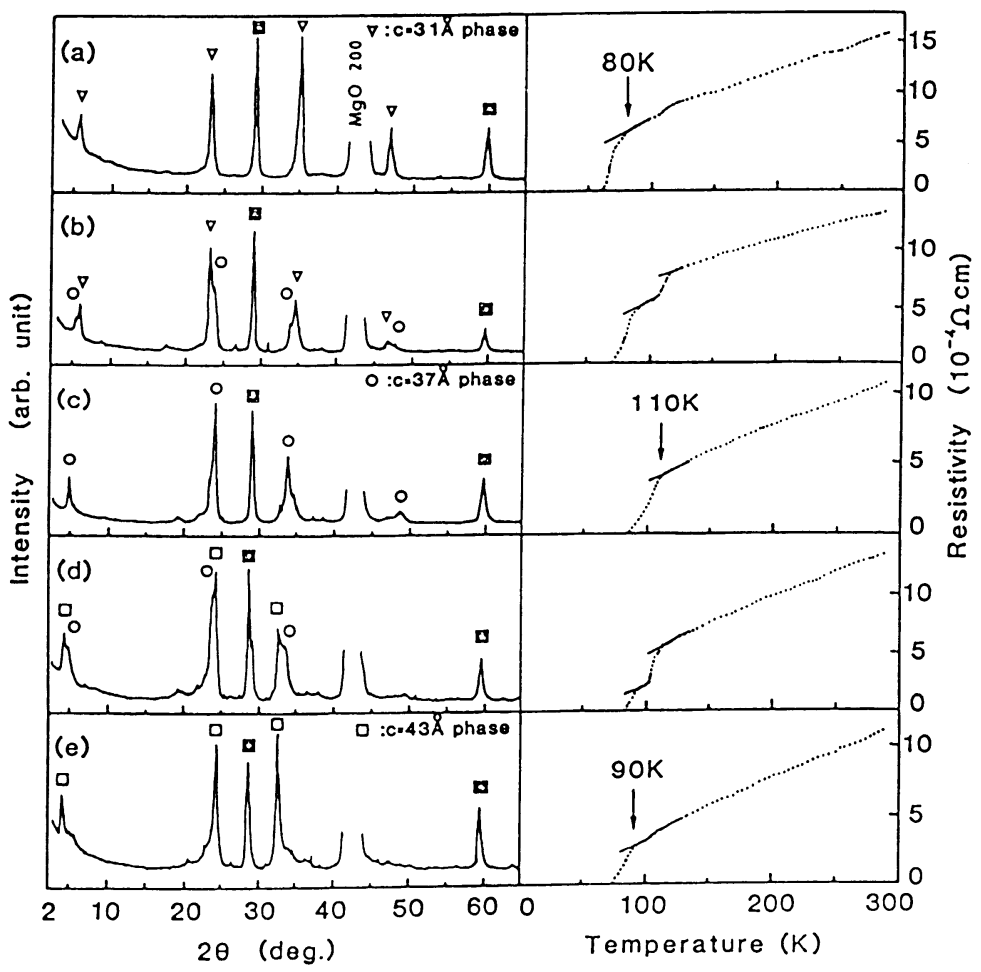

Fig. $11 \mathrm{X}$-ray diffraction patterns and resistivity-temperature characteristics for the phase-controlled $\mathrm{Bi}-\mathrm{Sr}-\mathrm{Ca}-\mathrm{Cu}-\mathrm{O}$ thin films.

(a ) $\mathrm{Bi}_{2} \mathrm{Sr}_{2} \mathrm{CaCu}_{3} \mathrm{O}_{x}$; (b) $\mathrm{Bi}_{2} \mathrm{Sr}_{2} \mathrm{CaCu}_{2} \mathrm{O}_{x} / \mathrm{Bi}_{2} \mathrm{Sr}_{2} \mathrm{Ca}_{2} \mathrm{Cu}_{3} \mathrm{O}_{y}$, (c) $\mathrm{Bi}_{2} \mathrm{Sr}_{2} \mathrm{Ca}_{2} \mathrm{Cu}_{3} \mathrm{O}_{y}$;

(d) $\mathrm{Bi}_{2} \mathrm{Sr}_{2} \mathrm{Ca}_{2} \mathrm{Cu}_{3} \mathrm{O}_{y} / \mathrm{Bi}_{2} \mathrm{Sr}_{2} \mathrm{Ca}_{3} \mathrm{Cu}_{4} \mathrm{O}_{z}$ and ; (e ) $\mathrm{Bi}_{2} \mathrm{Sr}_{2} \mathrm{Ca}_{3} \mathrm{Cu}_{4} \mathrm{O}_{z} \cdot$ Film thickness ; 300-400 А.

ためintergrowth 現象などが発生し，良好な超伝導特性 は得られていない。現在単一相の Bi 系超伝導薄膜は,

多元スパッ夕においてのみ得られており, この方法で形 成された, $\mathrm{Cu}-\mathrm{O} 4$ 層の $\mathrm{Bi}_{2} \mathrm{Sr}_{2} \mathrm{Ca}_{3} \mathrm{Cu}_{4} \mathrm{O}_{x}$ が, 人工的に 合成された $\mathrm{Cu}-\mathrm{O}$ 層最高の超伝導材料である。これは, 原子層制御においてのみ合成される超伝導体である。 超伝導転移温度は, Table 1 にも示すごとく, $90 \mathrm{~K}$ と $\mathrm{Cu}-\mathrm{O} 3$ 層の通常の $110 \mathrm{~K}$ 高温相より低い。

なお，乙の種の原子層制御による蒸着膜は, ALOS (Artificially Layered Oxide Superconductors) ともよ れば，新しい材料の探索の手段としても興味がもたれて (る52)。

\section{5. まとめ}

$\mathrm{Bi}$ 系の高温超伝導体が発見されてから, わずか 1 年あ まりの間に数 100 を数える薄膜化の研究論文が発表され た。これらの多くは作成プロセスに関する研究である。

この場合, 薄膜化はバルクセラミックスの形成のよう な熱平衡的なプロセスより，非熱平衡的な成長機構と関
連する。しかしながら, 非熱平衡的な要素を考虑した薄 膜合成機構に関する基礎的な研究はほとんど行われてい ない。今後, 薄膜化に関する地道な研究を進めること が, 肝要で, これにより新しい材料が創成されるととも に, 現在全く手がつけられていない, 高温超伝導現象に 対する薄膜効果む明らかにされる。乙れが, この種の材 料のエレクトロニクス分野への応用の近道でもある ${ }^{53)}$ 。

\section{文献}

1) J. G. Bednorz and K. A. Müller : Z. Phys. B 64 189 (1986).

2) K. Kishio, K. Kitazawa, N. Sugii, S. Kanbe, K. Fueki, H. Takagi and S. Tanaka: Chem. Lett. 635 (1987).

3) M. A. Subramanian, J. Gopalakrishnan, C. C. Torardi, T. R. Askew, R. B. Flippen, A. W. Sleight, J. J. Lin and S. J. Poon: Science 240, 495 (1988).

4) M. K. Wu, J. R. Ashburn, C. J. Torng, P. H. Hor, R. L. Meng, L. Gao, Z. J. Huang, Y. Q. Wang and C. W. Chu : Phys. Rev. Lett. 58, 908 
(1987).

5) A. F. Marshall, R. W. Barton, K. Char, A. Kapitulnik, B. Oh, R. H. Hammond and S. S. Laderman: Phys. Rev. B 37, 9353 (1988).

6) C. Michel, M. Hervieu, M. M. Borel, A. Grandin, F. Deslandes, J. Provost and B. Raveau: Z. Phys. B 68, 421 (1987).

7) J. Akimitsu, A. Yamazaki, H. Sawa and H. Fujiki: Jpn. J. Appl. Phys. 26, L 2080 (1987).

8) H. Maeda, Y. Tanaka, M. Fukutomi and T. Asano: Jpn. J. Appl. Phys. 27, L 209 (1988).

9) K. Wasa, H. Adachi, Y. Ichikawa, K. Hirochi and K. Setsune : Proceedings of the 1 st International Symposium on Superconductivity (ISS '88) (1988) p. 483 ; H. Adachi S. Kohiki, K. Setsune, T. Mitsuyu and K. Wasa: Jpn. J. Appl. Phys. 27, L 1883 (1988).

10) S. Kondoh, Y. Ando, M. Onoda, M. Sato and J. Akimitsu: Solid State Commun. 65, 1329 (1988).

11) Z. Z. Sheng, A. M. Hermann, A. El Ali, C. Almasan, J. Estrada, T. Datta and R. J. Matson : Phys. Rev. Lett. 60, 937 (1988).

12) Z. Z. Sheng and A. M. Hermann: Nature 332, 138 (1988).

13) S. S. P. Parkin, V. Y. Lee, E. M. Engler, A. I. Nazzal, T. C. Huang, G. Gorman, R. Savoy and R. Beyers: Phys. Rev. Lett. 60, 2539 (1988).

14) R. Beyers, S. S. P. Parkin, V. Y. Lee, A. I. Nazzal, R. Savoy, G. Gorman, T. C. Huang and S. LaPlaca: Appl. Phys. Lett. 53, 432 (1988).

15) S. S. P. Parkin, V.Y. Lee, A. I. Nazzal, R. Savoy and R. Beyers : Phys. Rev. Lett. 61, 750 (1988)

16) H. Ihara, R. Sugise, M. Hirabayashi, N. Terada, M. Jo, K. Hayashi, A. Negishi, M. Tokumoto, Y. Kimura and T. Shimomura: Nature 334, 510 (1988).

17) J. Akimitsu, S. Suzuki, M. Watanabe and H. Sawa: Jpn. J. Appl. Phys. 27, L 1859 (1988).

18) Y. Tokura, H. Takagi and Uchida : Nature 337, 345 (1989).

19) R. J. Cava, B. Batlogg, J. J. Krajewski, R. Farrow, L. W. Rupp Jr, A. E. White, K. Short, W. F. Peck and T. Kometani : Nature 332, 814 (1988).

20）和佐清孝, 早川 茂：スパッタ技術（共立, 1988).

21) K. Wasa, M. Kitabatake, H. Adachi, K. Hirochi, Y. Ichikawa and K. Setsune : Proc. International Conference on Metallugical coatings, (1989) paper c 4-12.

22) 川合知二 : パリティ 4, 59 (1989).

23) K. Wasa, H. Adachi, Y. Ichikawa, K. Setsune and K. Hirochi : Rev. Solid State Sci. 2, 453 (1988)

24) M. Oikawa and K. Toda : Appl. Phys. Lett. 29,
491 (1976).

25) D. Dijkkamp, T. Venkatesan, X. D. Wu, S. A. Shaheen, N. Jisrawi, Y. H. Min-Lee, W. L. McLean and M. Croft: Appl. Phys. Lett. 51, 619 (1987).

26) T. Fukami and T. Sakuma : Jpn. J. Appl. Phys. 20, 1599 (1981).

27) T. Nakagawa, J. Yamaguchi, M. Okuyama and Y. Hamakawa: Jpn. J. Appl. Phys. 21, L 655 (1982).

28) J. D. Jorgensen, M. A. Beno, D. G. Hinks, L. Solderholm, K. J. Volin, R. L. Hitterman, J. D. Grace and I. K. Shuller: Phys. Rev. B 36, 3608 (1987).

29) S. Hayashi, T. Kamada, K. Setsune, T. Hirao, K. Wasa and A. Matsuda : Jpn. J. Appl. Phys. 27, L 1257 (1988).

30) 笛木和雄 : 表面科学 9, 480 (1988).

31) H. Adachi, K. Setsune and K. Wasa : Jpn. J. Appl. Phys. Suppl. 26-3, 1139 (1987).

32) S. Kohiki, K. Hirochi, H. Adachi, K. Setsune and K. Wasa : Phys. Rev. B 38, 9201 (1988) ; 39 (1988) (in press).

33) H. Adachi, K. Setsune, K. Hirochi, T. Kamada and $\mathrm{K}$. Wasa : Proc. of international Conf. on High-Temp. Superconductors and Materials and Meachanisms of Superconductivity, E 12, (Swizerland, 1988).

34) J. H. Kang, R. T. Kampwith and K. E. Gray : Appl. Phys. Lett. 52, 2080 (1988) ; J. H. Kang, R. T. Kampwith, K. E. Gray, S. Marsh and E. A. Huff : Phys. Lett. 128, 102 (1988).

35) K. Kuroda, M. Mukaido, M. Yamamoto and S. Miyazawa: Jpn. J. Appl. Phys. 27, L 625 (1988).

36) C. E. Rice, A. F. J. Levi, R. M. Fleming, P. Marsh, K. W. Baldwin, M. Anzlower, A. E. White, K. T. Short, S. Nakahara and H. L. Stormer: Appl. Phys. Lett. 52, 1828 (1988).

37) M. Kanai, T. Kawai, M. Kawai and S. Kawai : Jpn. J. Appl. Phys. 27, L 1293 (1988).

38) R. D. Lolentz and J.H. Sexton: Appl. Phys. Lett. 53, 1654 (1988).

39) H. Yamane, H. Kurosawa, T. Hirai, H.Iwasaki, N. Kobayashi and Y. Moto: Jpn. J. Appl. Phys. 27, L 1495 (1988).

40) L. S. Hung, J. A. Agostinelli, G. R. Paz-Pujalt and J.M. Mir: Appl. Phys. Lett. 53, 2450 (1988).

41) J. J. Yeh and H. Hong: Appl. Phys. Lett. 54, 769 (1989).

42) T. Kato, T. Doi, T. Kumagai and S. Matsuda : Jpn. J. Appl. Phys. 27, L 1097 (1988).

43) S. Hatta, K. Hirochi, H. Adachi, T. Kamada, Y. Ichikawa, K. Setsune and K. Wasa : Jpn. J. Appl. Phys. 27, 1646 (1988).

44) K. Setsune, K. Hirochi, H. Adachi, Y. Ichikawa 
and K. Wasa : Appl. Phys. Lett. 15, 600 (1988).

45) 日経超電導, 13 (1988. 10.31).

46) S. Hatta, Y. Ichikawa, H. Adachi and K. Wasa : Jpn. J. Appl. Phys. 28, (1988) (in press).

47) W. Staguhn, K. Nakao, N. Miura, M. Von Ortenberg, S. Hatta, Y. Ichikawa and K. Wasa: Technical Report of ISSP Ser. A 2102 (1989) (Boston, 1988).

48) S. Hatta, Y. Ichikawa, H. Adachi, K. Setsune, K. Hirochi and K. Wasa : 1988 MTS Fall Meeting Abstracts 207.

49) J. Satoh, M. Kaise, K. Nakamura and K. Ogawa : Conference on the Sci. and Technol. of Thin Film Superconductors, Colorado Spring, Colorado Nov. 14-18 (1988).
50) J.-I. Fujita, T. Tatsumi, T. Yoshitake and H. Igarashi : Conference on the Sci. and Technol. of Thin Film Superconductors, Colorado Spring, Collorado Nov. 14-18 (1988).

51) T. Kawai, M. Kanai and S. Kawai : Conference on the Sci. and Technol. of Thin Film Superconductors, Colorado Spring, Colorado Nov. 14-18, (1988).

52) J. R. Kwo: Conference on the Sci. and Technol. of Thin Film Superconductors Colorado Spring, Colorado (1988), Short Cource of Introductory Reviews on Thin Film Superconductors.

53）和佐清孝, 瀬恒謙太郎：材料科学（1989）（投稿 中). 